\title{
Clinically relevant genetic variants of drug- metabolizing enzyme and transporter genes detected in Thai children and adolescents with autism spectrum disorder
}

\author{
This article was published in the following Dove Press journal: \\ Neuropsychiatric Disease and Treatment \\ 13 April 2016 \\ Number of times this article has been viewed
}

\author{
Sadeep Medhasi ${ }^{1-3}$ \\ Ekawat Pasomsub 4 \\ Natchaya Vanwong ${ }^{1,2}$ \\ Nattawat Ngamsamut ${ }^{5}$ \\ Apichaya Puangpetch ${ }^{1,2}$ \\ Montri Chamnanphon ${ }^{1,2}$ \\ Yaowaluck Hongkaew ${ }^{1,2}$ \\ Penkhae Limsila ${ }^{5}$ \\ Darawan Pinthong ${ }^{3}$ \\ Chonlaphat Sukasem ${ }^{1,2}$ \\ 'Division of Pharmacogenomics and \\ Personalized Medicine, Department \\ of Pathology, Faculty of Medicine \\ Ramathibodi Hospital, Mahidol University, \\ Bangkok, Thailand; ${ }^{2}$ Laboratory for \\ Pharmacogenomics, Somdech Phra \\ Debaratana Medical Center, Faculty of \\ Medicine Ramathibodi Hospital, Mahidol \\ University, Bangkok, Thailand; ${ }^{3}$ Department \\ of Pharmacology, Faculty of Science, \\ Mahidol University, Bangkok, Thailand; \\ ${ }^{4}$ Division of Virology, Department of \\ Pathology, Faculty of Medicine Ramathibodi \\ Hospital, Mahidol University, Bangkok, \\ Thailand; ${ }^{5}$ Yuwaprasart Waithayopathum \\ Child and Adolescent Psychiatric Hospital, \\ Department of Mental Health Services, \\ Ministry of Public Health, Samut Prakarn, \\ Thailand
}

Correspondence: Chonlaphat Sukasem

Division of Pharmacogenetics and Personalized

Medicine, Department of Pathology, Faculty

of Medicine Ramathibodi Hospital, Mahidol

University, 270, Rama 6 Road, Thung Phaya

Thai, Ratchathewi, Bangkok, 10400, Thailand

Tel +6622004331

Fax +66 22004332

Email chonlaphat.suk@mahidol.ac.th

\begin{abstract}
Single-nucleotide polymorphisms (SNPs) among drug-metabolizing enzymes and transporters (DMETs) influence the pharmacokinetic profile of drugs and exhibit intra- and interethnic variations in drug response in terms of efficacy and safety profile. The main objective of this study was to assess the frequency of allelic variants of drug absorption, distribution, metabolism, and elimination-related genes in Thai children and adolescents with autism spectrum disorder. Blood samples were drawn from 119 patients, and DNA was extracted. Genotyping was performed using the DMET Plus microarray platform. The allele frequencies of the DMET markers were generated using the DMET Console software. Thereafter, the genetic variations of significant DMET genes were assessed. The frequencies of SNPs across the genes coding for DMETs were determined. After filtering the SNPs, 489 of the 1,931 SNPs passed quality control. Many clinically relevant SNPs, including $C Y P 2 C 19 * 2, C Y P 2 D 6^{*} 10, C Y P 3 A 5^{*} 3$, and $S L C O 1 B 1 * 5$, were found to have frequencies similar to those in the Chinese population. These data are important for further research to investigate the interpatient variability in pharmacokinetics and pharmacodynamics of drugs in clinical practice.
\end{abstract}

Keywords: Thai population, ADME, pharmacokinetics, autism spectrum disorder, microarray, pharmacogenetics

\section{Introduction}

Autism spectrum disorder (ASD) is a global health concern where the patient demonstrates three core features: social withdrawal, verbal and nonverbal communication impairment, and stereotype behavior with restricted and repetitive activities and/or interests. ${ }^{1}$ Results have shown that males are more likely to have autism than females, with a prevalence ratio of 4:1.,3 Atypical antipsychotics, including risperidone and aripiprazole, both US Food and Drug Administration approved, have been used as a pharmacologic therapy for the treatment of behavioral symptoms (irritability and aggression) in addition to the psychoeducational therapy among children and adolescents. ${ }^{4,5}$ However, children and adolescents treated with antipsychotic drugs may be predisposed to side effects, such as weight gain, metabolic effects, endocrinal dysfunction, and tardive dyskinesia. ${ }^{6,7}$ Genetic variations in drug-metabolizing enzymes (DMEs), drug transporters, and drug targets are important determinants of efficacy and toxicity in pharmacotherapy among patients. ${ }^{8}$ Individual variability in drug response poses a major challenge in drug therapy, drug development, and drug regulation. ${ }^{9}$ A better account of genetic variability and implementation of personalized 
medicine are essential in individual patients to improve the drug therapy by enabling clinicians to prescribe the right medication in the right dose to achieve maximum therapeutic efficacy with minimum adverse drug reactions. ${ }^{10}$ Pharmacogenetics is the study of contribution of genetic differences to drug response between individuals. Advances in the field of molecular genotyping, such as DNA chips and microarrays, have facilitated the analysis of large genetic variations. ${ }^{11}$ Single-nucleotide polymorphisms (SNPs) are an important marker for pharmacogenetic studies, which can be used for phenotypic association with a functional variant and for optimizing personalized drug therapy. ${ }^{12,13}$ Investigations on animal models of autism have revealed the association between polymorphism in serotonin transporter (5-HTT) and autism. ${ }^{14}$ In humans, genetic studies in patients with ASD have revealed the polymorphisms in $C Y P 1 A 2^{*} 1 F$ and its association with susceptibility to ASD, ${ }^{15}$ and another polymorphism contributing to ASD is COMT Val58Met. ${ }^{16}$

Polymorphisms in DMEs and transporters (DMETs) across different populations have been reported with varying frequencies of allelic variation, suggesting interethnic differences in response to drug therapy. Patients are classified as poor metabolizer (PM), intermediate metabolizer, extensive metabolizer, and ultrarapid metabolizer, leading to no activity, reduced activity, normal activity, and increased activity, respectively, based on the DME genetic polymorphisms. ${ }^{17}$ The most common cytochrome $\mathrm{P} 450$ polymorphisms are found in $C Y P 2 C 9$, CYP2C19, and CYP2D6 as identified to date (http:// www.cypalleles.ki.se). The important Phase II enzymes exhibiting genetic polymorphisms, which determine the fate of the drugs, include uridine diphosphate glucuronosyltransferase (UGT), glutathione $S$-transferase (GST), sulfotransferase, $N$-acetytransferase (NAT), and thioupurine methyltransferase (TPMT). Some of the best characterized drug transporter genes implicated in drug metabolism and response include the adenosine triphosphate (ATP)-binding cassette (ABC) family, such as $A B C B 1, A B C C 1, A B C C 2$, and $A B C G 2$, and solute carrier (SLC) family proteins, such as $O C T 1, O A T P 1 B 1$, and $O A T .{ }^{18,19}$ Several pharmacogenetic biomarkers of DMETs are documented in PharmGKB (https://www.pharmgkb.org/), with evidence from different populations. There is a considerable difference in the frequency of genetic polymorphisms associated with drug response, across and within populations. ${ }^{20}$ The DMET genes have greater interindividual variability in expression as compared to non-DMET genes. ${ }^{21}$ A study investigating the frequencies of DMET SNPs among Thais as well as compared to other ethnic populations revealed significant differences in the distribution of several clinically important genetic polymorphisms among absorption, distribution, metabolism, and elimination genes. ${ }^{22}$ Integrating pharmacogenetics into clinical practice has proven to be a costsaving and improved therapeutic outcome for patients, with the avoidance of medication adverse effects. ${ }^{23}$ There is a critical need to understand and establish the frequency of genetic variants and implement the knowledge of genetic variation in DMET genes in the Thai population to construct dosing guidelines, so as to improve the clinical efficacy and minimize the occurrence of adverse effects.

In this study, we used the DMET ${ }^{\text {TM }}$ Plus GeneChip microarray platform (Affymetrix Inc., Santa Clara, CA, USA), which is used to genotype markers across genes involved in drug pharmacokinetics. The main aim of this study was to investigate the frequency of DMET genetic variations in the Thai population. The genetic database derived from this study will help in determining the pattern of SNPs in DMET genes among Thai population and correlate the genetic information with the drug response and adverse side effects to produce the significant clinical associations.

\section{Materials and methods Participants}

Blood samples were collected from the 119 Thai children and adolescents with ASD (according to the Diagnostic and Statistical Manual of Mental Disorders, Fourth Edition criteria) at Yuwaprasart Waithayopathum Child and Adolescent Psychiatric Hospital. Participants were included who were prescribed with risperidone once or twice a day and the dosing was flexible as well. Patients with severe physical disabilities and currently being treated with other antipsychotic drugs were excluded from the study. However, stimulants were allowed in the case of co-occurring attention deficit/hyperactivity disorder. The purpose and experimental procedures were explained to the parents of the participants before obtaining written informed consent from all of the participants' parents. The study was conducted in accordance with the principles of the Declaration of Helsinki and locally approved by the Ramathibodi Ethics Committee (Bangkok, Thailand).

\section{Sample collection and genomic DNA (gDNA) extraction}

Blood samples were collected into EDTA tubes with the assistance of a trained laboratory technician and were then brought to the laboratory of Pharmacogenomics and Personalized Medicine, Ramathibodi Hospital, in a well-insulated 
ice box. The samples were then stored at $<-70^{\circ} \mathrm{C}$ for the subsequent extraction of gDNA.

gDNA was isolated from EDTA-whole blood using a MagNA Pure Compact System (Hoffman-La Roche Ltd., Basel, Switzerland), according to the manufacturer's instructions, and quantified by a NanoDrop ${ }^{\mathrm{TM}} 1000$ Spectrophotometer at $260 \mathrm{~nm}$ (Thermo Fisher Scientific, Waltham, MA, USA).

\section{Genotyping and marker selection}

Samples were genotyped using the DMET platform (DMET Plus) according to the standard protocol described by the manufacturer. The DMET TM Plus GeneChip enables the genotyping of 1,936 genetic variants (1,931 SNPs and five copy number variations) of 231 genes having functional significance in Phase I and Phase II DME genes and drug transporter coding genes. ${ }^{20}$ The DMET Plus platform examines the genetic variations, including biallelic and triallelic SNPs, copy number variations, and insertions/deletions. ${ }^{24}$ Genotype analysis using the DMET Plus platform is based on an efficient and comprehensive molecular inversion probe technology. ${ }^{25,26}$ DNA samples on the DMET Plus array were scanned with the GeneChip Scanner 3000 (Affymetrix Inc.). The genotype profile of 1,931 SNPs was generated by DMET ${ }^{\text {TM }}$ Console Software $^{\circledR}$ (Version 1.3; Affymetrix Inc.).

\section{Quality control}

Quality control of the samples and SNPs was performed as shown in Figure 1. Individual samples were considered passed or in bounds if they had genotyping calls $>90 \%$. The markers with genotyping call rate $<95 \%$, deviation from Hardy-Weinberg equilibrium (HWE) at $P>0.001$, minor allele frequency $(\mathrm{MAF})<0.05$, and variants on chromosome $\mathrm{X}$ were discarded.

\section{Statistical analysis}

Data are presented as median and ranges, or as otherwise specified. The Haploview 4.2 software was used for checking HWE, along with MAF, and filtering markers according to the criteria set for quality control. ${ }^{27}$

\section{Results}

\section{Patient characteristics and selection of markers}

Most of the participants were males $(87.1 \%)$ and had a median age of 8.8 years (range 3.3-18.3 years). A total of $1,681 \mathrm{SNPs}$ passed the first quality control filter with call rate of $>95 \%$. Only 489 SNPs were included for the assessment

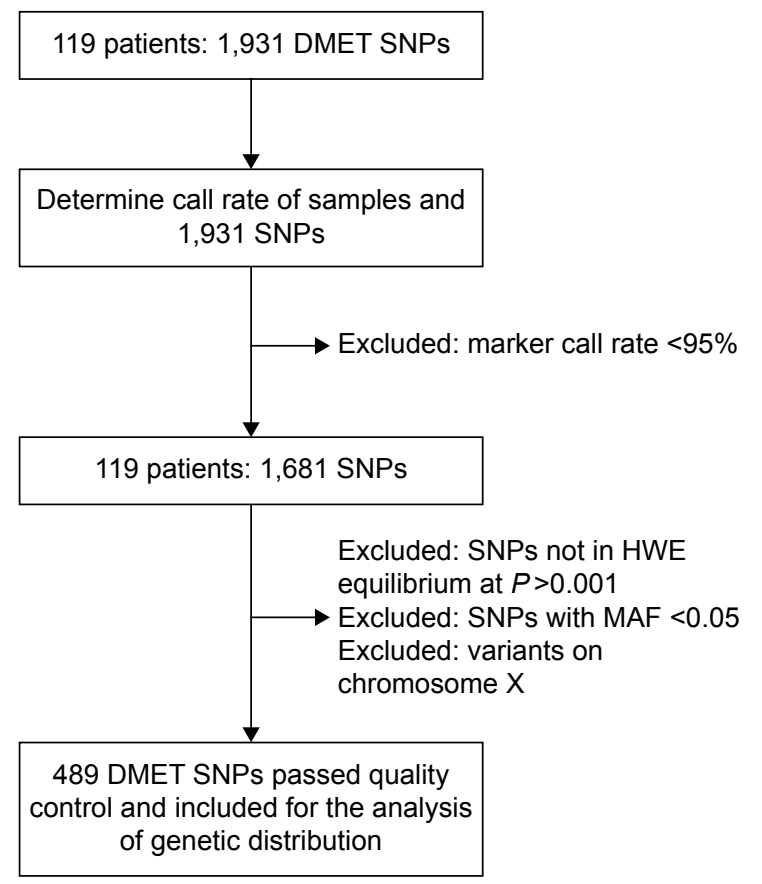

Figure I Flow diagram of genetic marker selection. Abbreviations: DMET, drug-metabolizing enzymes and transporters; HWE, Hardy-Weinberg equilibrium; MAF, minor allele frequency; SNPs, single-nucleotide polymorphisms.

of genetic prevalence after considering the quality control filter removing the SNPs that were not in HWE, MAF $<0.05$, and SNPs on the X chromosome (46 SNPs) (Figure 1). The average call rate of the sample was $99.23 \%$.

\section{Allele frequency distribution of common functional polymorphisms of Phase I enzymes}

The observed minor allele frequencies of common polymorphisms in CYP enzymes with their clinical or functional relevance are presented in Table 1 . We identified 32 CYP genes with different markers prevalent in the Thai population. The prevalence rates of some pharmacologically and clinically relevant CYP polymorphisms observed were as follows: CYP1A1*2C (30.3\%), CYP1A2*1C (30.3\%), CYP1A2*1F (23.9\%), CYP2A6*9 (15.3\%), CYP2B6*4 (32.8\%), CYP2B6*6 (28.4\%), CYP2C19*2 (33.2\%), CYP2C19*3 (5\%), CYP2D6 100C > T (41.2\%), CYP2D6 2850C >T (10.1\%), CYP3A5*3 (37\%), and CYP3A7*2 (35.8\%).

\section{Allele frequency distribution of common functional polymorphisms of Phase II DMEs}

We detected different allele frequencies of common Phase II DMEs, with a wide frequency range from $5 \%$ to $49 \%$ in 
Table I Minor allele frequencies of common functional polymorphisms in major human CYP genes in Thai children and adolescents with autism spectrum disorder (sample size $=119$ )

\begin{tabular}{|c|c|c|c|c|}
\hline Gene & dbSNP RS ID & Common name & $\begin{array}{l}\text { Minor allele } \\
\text { frequency }\end{array}$ & Clinical relevance \\
\hline CYPIAI & $\begin{array}{l}\text { rs1048943 } \\
\text { rs4646422 }\end{array}$ & $\begin{array}{l}\text { CYPIAI*2C_2454A }>G(1462 \mathrm{~V}) \\
\text { CYPIAI_I34G }>A(G 45 D)\end{array}$ & $\begin{array}{l}0.303 \\
0.08\end{array}$ & $\begin{array}{l}\text { - In } * 2 C \text { variant, the } A A \text { genotype has decreased } \\
\text { progression-free survival time compared to } A G \text { and GG } \\
\text { genotypes in women with breast cancer treated with } \\
\text { capecitabine and docetaxel }\left.\right|^{41}\end{array}$ \\
\hline CYPIA2 & $\begin{array}{l}\text { rs20695I4 } \\
\text { rs76255I } \\
\text { rs2470890 }\end{array}$ & $\begin{array}{l}\text { CYPIA2*IC_-3860G }>\text { A (Promoter }) \\
\text { CYPIA2*IF_-I63C }>\text { A(Promoter }) \\
\text { CYPIA2_5347T }>C(N 5 I 6 N)\end{array}$ & $\begin{array}{l}0.303 \\
0.239 \\
0.206\end{array}$ & $\begin{array}{l}\text { - Genotypes } A A \text { and } A G \text { are associated with decreased } \\
\text { metabolism of theophylline as compared to genotype GG } \\
\text { in patients with asthma for } * I C^{42} \\
\text { - Allele } A \text { is associated with tardive dyskinesia in patients } \\
\text { taking antipsychotic medications compared to allele } G \\
\text { among smokers for } * I C \text { polymorphism } \\
\text { - Patients with } * I F \text { variants are associated with reduced } \\
\text { serum concentration of olanzapine and subsequent } \\
\text { decreased response }{ }^{44}\end{array}$ \\
\hline CYP2A6 & $\begin{array}{l}\text { rs } 28399433 \\
\text { rs } 1137115 \\
r s 4079369 \\
\text { rs } 8192729\end{array}$ & $\begin{array}{l}\text { CYP2A6*9_-48T }>\text { G(Promoter) } \\
\text { CYP2A6_5IG }>A(V I 7 V) \\
\text { CYP2A6_3570C }>\text { G } \\
\text { CYP2A6_5336G }>A\end{array}$ & $\begin{array}{l}0.153 \\
0.261 \\
0.076 \\
0.076\end{array}$ & $\begin{array}{l}\text { CYP2A6*9 is associated with increased plasma } \\
\text { concentration of efavirenz }{ }^{45}\end{array}$ \\
\hline CYP2B6 & $\begin{array}{l}r s 8192709 \\
r s 4803418 \\
r s 2279343 \\
r s 3745274 \\
r s 2279344 \\
r s 8192719\end{array}$ & $\begin{array}{l}\text { CYP2B6*2_64C }>\text { T(R22C) } \\
\text { CYP2B6_I4593C }>\text { G } \\
\text { CYP2B6*4_I8053A }>\text { G(K262R) } \\
\text { CYP2B6*6_I563IG }>\text { T(Q172H) } \\
\text { CYP2B6_I8273G >A } \\
\text { CYP2B6_2I563C >T }\end{array}$ & $\begin{array}{l}0.055 \\
0.382 \\
0.328 \\
0.284 \\
0.286 \\
0.282\end{array}$ & $\begin{array}{l}\text { - CYP2B6*4 is associated with increased plasma } \\
\text { concentration of efavirenz } \\
\text { - CYP2B } 6 * 6 \text { is associated with increased efavirenz plasma } \\
\text { concentrations }^{47}\end{array}$ \\
\hline CYP2CI9 & $\begin{array}{l}\text { rs4244285 } \\
\text { rs4986893 }\end{array}$ & $\begin{array}{l}\text { CYP2CI9*2_I9154G }>A(P 227 P) \\
\text { CYP2CI9*3_I7948G }>A(W 212 X)\end{array}$ & $\begin{array}{l}0.332 \\
0.05\end{array}$ & $\begin{array}{l}\text { CYP2C19*2 and } * 3 \text { is known to affect the metabolism } \\
\text { and/or responses of several drugs, like amitriptyline, } \\
\text { clopidogrel, sertraline, citalopram, and escitalopram } \\
48-52\end{array}$ \\
\hline CYP2D6 & $\begin{array}{l}\text { rs II } 35840 \\
\text { rs } 16947 \\
\text { rs } 1058164 \\
\text { rs } 1065852 \\
\text { rs } 1080985 \\
\text { rs } 28360521\end{array}$ & 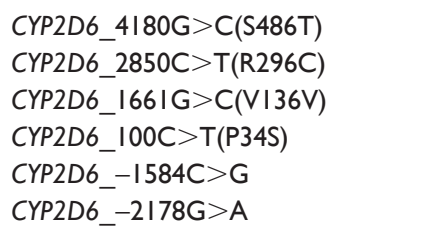 & $\begin{array}{l}0.298 \\
0.101 \\
0.286 \\
0.412 \\
0.071 \\
0.397\end{array}$ & $\begin{array}{l}\text { - Amitriptyline, nortriptyline, paroxetine, codeine, and } \\
\text { tramadol are some of the drugs whose pharmacokinetics, } \\
\text { response, and toxicity are known to be influenced by } \\
\text { CYP2D6 polymorphisms }{ }^{53-57}\end{array}$ \\
\hline CYРЗА5 & rs776746 & CYP3A5*3_6986A $>$ G(SpliceDefect $)$ & 0.37 & $\begin{array}{l}\text { Patients with } * 3 / * 3 \text { genotype show higher } \\
\text { concentration of tacrolimus as compared to } *|*| \\
\text { and } * I * 3 \text { genotypes }{ }^{58}\end{array}$ \\
\hline CYP3A7 & rs225740I & CYP3A7*2_2604IC > G(T409R) & 0.358 & $\begin{array}{l}\text { - Presence of } C Y P 3 A 7^{*} 2 \text { is associated with higher } \\
\text { concentration/dose ratio of tacrolimus }{ }^{59}\end{array}$ \\
\hline
\end{tabular}

Note: dbSNP RS ID is an identification tag assigned by the National Center for Biotechnology Information to a group of single nucelotide polymorphisms (SNPs) that map to an identical location in the SNP database.

this Thai population, as shown in Table 2. Among UGT1A1 polymorphisms, $U G T 1 A 1 * 60$ was the most prevalent (36.1\%) in this study group. The prevalence rates of other notable clinically significant variants among several Phase II enzymes were as follows: $U G T 2 B 7^{*} 2(31.5 \%), U G T 1 A 7^{*} 12(15.1 \%)$, GSTA5 c. $-31+2057 \mathrm{C}>\mathrm{T}(35.7 \%)$, GSTP1*B (27.5\%), GSTZ1 c. $94 \mathrm{G}>\mathrm{A}(39.5 \%), N A T 2 * 13$ (45.4\%), and $N A T 2 * 6(27.7 \%)$.

\section{Allele frequency distribution of common functional polymorphisms of drug transporters}

Table 3 shows the allele frequencies of drug transporter genes in Thai population. Among the important efflux
ABCB1 transporters, the MAF of $A B C B 11236 \mathrm{C}>\mathrm{T}$ and $3435 \mathrm{C}>\mathrm{T}$ exhibited prevalence rates of $34.5 \%$ and $43.7 \%$, respectively. Other ABC SNPs with clinical relevance exhibited prevalence rates of rs212091 (15.7\%), rs717620 (22.3\%), rs2273697 (6.7\%), rs3740066 (24.3\%), and 30.7\% for $A B C G 2421 \mathrm{C}>\mathrm{A}$.

The uptake SLC transporters (OCT1, OCT2, OATP1A2, and OATP1B2) were present with at least one variant allele in this study group (data for all variants not shown). Among the OCT1 family, the two variants rs628031 (Val408Met, $1222 \mathrm{G}>\mathrm{A}$ ) and rs 1867351 (Ser52Ser, 156T $>$ C) had higher frequency of $33.9 \%$ and $31.9 \%$, respectively. The pharmacologically important variants $S L C O 1 B 1^{*} 1 B, S L C O 1 B 1 * 5$, 
Table 2 Minor allele frequencies of common functional polymorphisms in major human Phase II drug-metabolizing enzyme genes in Thai children and adolescents with autism spectrum disorder (sample size $=119$ )

\begin{tabular}{|c|c|c|c|c|}
\hline Gene & dbSNP RS ID & Common name & $\begin{array}{l}\text { Minor allele } \\
\text { frequency }\end{array}$ & Clinical relevance \\
\hline \multirow[t]{6}{*}{ UGTIAI } & rs4I48323 & UGTIAI*6_c.2IIG >A(G7|R) & 0.067 & \multirow{6}{*}{$\begin{array}{l}\text { - UGTIAI*6 is associated with increased risk of } \\
\text { neutropenia when treated with irinotecan } \\
\text { - UGTIAI*93 is associated with increased risk } \\
\text { of hematologic toxicity in irinotecan-treated } \\
\text { patients }^{33}\end{array}$} \\
\hline & rs4I 24874 & UGTIAI*60_c.-3279T>G(Promoter) & 0.361 & \\
\hline & rs 10929303 & UGTIAI*76_c.*2IIC >T(3'UTR) & 0.088 & \\
\hline & rs8330 & UGTIAI*79_c.*440C $>$ G(3'UTR $)$ & 0.082 & \\
\hline & rs887829 & UGTIAI*80_c. $-364 \mathrm{C}>\mathrm{T}$ & 0.13 & \\
\hline & rs 10929302 & UGTIAI*93_c.-3I56G >A(Promoter) & 0.126 & \\
\hline UGTIA7 & rs7586110 & UGTIA7*I2_c.-57T>G(5'UTR $)$ & 0.151 & $\begin{array}{l}\text { - UGTIA } 7^{*} / 2 \text { is associated with increased risk } \\
\text { of hyperbilirubinemia when treated with } \\
\text { atazanavir }^{35}\end{array}$ \\
\hline \multirow[t]{2}{*}{ UGT2B7 } & rs7439366 & UGT2B7*2_c.802C > T(H268Y) & 0.315 & \multirow[b]{2}{*}{$\begin{array}{l}\text { - Genotype TT shows better response to } \\
\text { lorazepam and valproic acid as compared to } \\
\text { genotype CC in UGT2B } 7^{* 2} \text { polymorphism }{ }^{60} \\
\text { - UGT2B } 7^{*} 3 \text { is associated with decreased } \\
\text { clearance of carvedilol }\left.\right|^{61}\end{array}$} \\
\hline & rs 12233719 & UGT2B7*3_c.2IIG > T(A7IS) & 0.084 & \\
\hline \multirow[t]{2}{*}{ GSTA5 } & rs $47 I 5354$ & GSTA5_c.-3I+2057C $>$ T & 0.357 & \multirow{2}{*}{$\begin{array}{l}\text { rs47I5354 and rs7746993, both combined, } \\
\text { are associated with decreased busulfan } \\
\text { clearance }^{62}\end{array}$} \\
\hline & rs7746993 & GSTA5_-8526G $>$ T & 0.147 & \\
\hline GSTPI & rs 1695 & GSTPI*B_c.3I3A $>G(\mid 105 \mathrm{~V})$ & 0.275 & $\begin{array}{l}\text { - GSTPI*B is associated with increased response } \\
\text { and decreased severity of toxicity among } \\
\text { patients with breast cancer treated with } \\
\text { cyclophosphamide and epirubicin }{ }^{63} \\
\text { - Efficacy and/or toxicity of oxaliplatin, } \\
\text { methotrexate, and fluorouracil are associated } \\
\text { with GSTPI*B variant }{ }^{64}\end{array}$ \\
\hline \multirow[t]{2}{*}{ GSTZI } & rs 1046428 & GSTZI_c.245C>T(T82M) & 0.055 & \multirow{2}{*}{$\begin{array}{l}\text { rs7975 and rs } 1046428 \text { are associated with } \\
\text { clearance of dichloroacetic acid }{ }^{65}\end{array}$} \\
\hline & rs7975 & GSTZI_c.94G >A(E32K) & 0.395 & \\
\hline \multirow[t]{5}{*}{ NAT2 } & rsI799929 & NAT2_c.48IC > T(LI6IL) & 0.078 & \multirow{5}{*}{$\begin{array}{l}\text { - rs } 1799929 \text { variant is associated with } \\
\text { hepatotoxicity when treated with } \\
\text { antituberculosis drugs }{ }^{66} \\
\text { - NAT2*5, } * 6, * 7 \text { and } * 13 \text { influence the } \\
\text { metabolism of isoniazid }{ }^{67}\end{array}$} \\
\hline & rs $180 \mid 280$ & NAT2*5_c.34IT >C $(I|| 4 T)$ & 0.092 & \\
\hline & rsI799930 & NAT2*6_c.590G $>A(R \mid 97 Q)$ & 0.277 & \\
\hline & rsI79993I & NAT2*7_c.857G >A(G286E) & 0.176 & \\
\hline & rs1041983 & NAT2*13_c.282C $>$ T(Y94Y $)$ & 0.454 & \\
\hline
\end{tabular}

Note: dbSNP RS ID is an identification tag assigned by the National Center for Biotechnology Information to a group of single nucelotide polymorphisms (SNPs) that map to an identical location in the SNP database.

and $S L C O 1 B 1 * 17$ had frequencies of $26.9 \%, 12.2 \%$, and $8.4 \%$, respectively.

\section{Discussion}

In this study population of 119 Thai children and adolescents with ASD, we have reported allele frequency of clinically relevant DMET SNPs. Among the 1,931 markers genotyped by the DMET assay, we detected $\sim 26 \%$ of SNPs distributed along the pharmacokinetic genes. Although, $87 \%$ of SNPs passed the $95 \%$ call rate criteria, many of the SNPs were discarded because they were monomorphic and had a prevalence of $<5 \%$. Our study sample was comprised of mostly males (87\%), and hence 46 SNPs on the X chromosome were excluded, as well. The SNPs reported in this study could serve as informative data in assessing the potential risk of therapeutic failure or adverse events in the Thai population, where there is little information available about the prevalence of variations across DMET genes. The DMET microarray technique proved to be a powerful tool enabling us to characterize the clinically important genetic variants among DMET genes.

The frequency of some alleles in this study showed similar prevalence with previous studies conducted in the Thai population. The allele frequencies of $C Y P 2 C 19 * 3$ (PM), CYP2D6*2, and CYP2D6*10 (decreased enzyme activity) were $5 \%, 10 \%$, and $41 \%$, respectively, in this study. Similar findings were reported by the group studying CYP2C19 and CYP2D6 polymorphisms and tamoxifen efficacy in Thai patients with breast cancer. ${ }^{28}$ CYP2C19*2, a PM, which has been shown to cause severe acute adverse drug reactions among Thai children treated with phenobarbital, ${ }^{29}$ showed a higher frequency of $33.2 \%$ in 
Table 3 Minor allele frequencies of common functional polymorphisms of drug transporter genes (ABC and SLC) in Thai children and adolescents with autism spectrum disorder (sample size $=119$ )

\begin{tabular}{|c|c|c|c|c|}
\hline Gene & dbSNP RS ID & Common name & $\begin{array}{l}\text { Minor allele } \\
\text { frequency }\end{array}$ & Clinical relevance \\
\hline$A B C B I(M D R I)$ & $\begin{array}{l}\text { rsII } 28503 \\
\text { rsI045642 } \\
\text { rsI0276036 }\end{array}$ & $\begin{array}{l}A B C B I \_c . \mid 236 C>T(G 4 \mid 2 G) \\
A B C B I \text {. } 3435 C>T(I I \mid 45 I) \\
A B C B I \text { c.IVS9-44A }>G\end{array}$ & $\begin{array}{l}0.345 \\
0.437 \\
0.339\end{array}$ & $\begin{array}{l}\text { - } A B C B / \text { I236C }>\mathrm{T} \text { is associated with overall } \\
\text { increased survival period among oxaliplatin- } \\
\text { treated patients with colorectal neoplasms }{ }^{68} \\
\text { - } A B C B / 3435 C>T \text { is associated with } \\
\text { increased serum concentration of digoxin }{ }^{69} \\
\text { and nevirapine-induced hepatotoxicity }{ }^{70} \\
\text { - rs } 10276036 \text { is associated with increased risk } \\
\text { of death in patients with osteosarcoma after } \\
\text { chemotherapy }{ }^{71}\end{array}$ \\
\hline$A B C C I(M R P I)$ & rs2|209| & $A B C C I$ _. $* 15 \mid 2 T>C$ & 0.157 & $\begin{array}{l}\text { - } r s 21209 \mid \text { is associated with virological } \\
\text { failure in antiretroviral drugs therapy }\end{array}$ \\
\hline$A B C C 2$ (MRP2) & $\begin{array}{l}\text { rs717620 } \\
\text { rs2273697 } \\
\text { rs3740066 }\end{array}$ & $\begin{array}{l}A B C C 2 \text { _c. }-24 C>T\left(5^{\prime} U T R\right) \\
A B C C 2 \text { _. } 1249 G>A(V 4 I 7 I) \\
A B C C 2 \text {. } 3972 C>T(\mid I 324 I)\end{array}$ & $\begin{array}{l}0.223 \\
0.067 \\
0.243\end{array}$ & $\begin{array}{l}\text { - rs7 } 17620 \text { and rs } 3740066 \text { affect the response } \\
\text { to antiepileptic drugs }{ }^{73} \\
\text { - rs7 I } 7620 \text { influences the metabolism of } \\
\text { erythromycin }{ }^{74} \text { and is associated with } \\
\text { toxicity among patients treated with } \\
\text { fluorouracil, leucovorin, and oxaliplatin } \\
\text { - rs } 2273697 \text { influences the pharmacokinetics } \\
\text { of talinol and irinotecan }\end{array}$ \\
\hline$A B C G 2(B C R P)$ & rs223II42 & ABCG2_c. $42 \mid \mathrm{C}>\mathrm{A}(\mathrm{Q}|4| \mathrm{K})$ & 0.307 & $\begin{array}{l}\text { rs } 223 \text { I I } 42 \text { is associated with the plasma } \\
\text { concentration of rosuvastatin } n^{78,79}\end{array}$ \\
\hline SLC22AI (OCTI) & $\begin{array}{l}\text { rsl86735I } \\
r s 683369 \\
r s 2282 \mid 43 \\
r s 62803 \mid\end{array}$ & 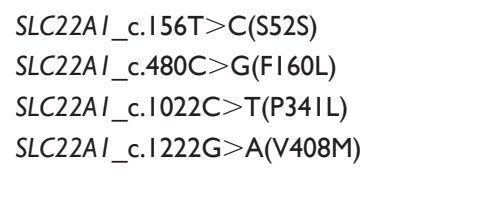 & $\begin{array}{l}0.319 \\
0.148 \\
0.13 \\
0.339\end{array}$ & $\begin{array}{l}\text { - c. } 480 C>G \text { polymorphism is associated with } \\
\text { pharmacokinetics of imatinib }{ }^{80} \\
\text { - rs } 62803 \mathrm{I} \text { is associated with } \\
\text { gastrointestinal side effects when treated } \\
\text { with metformin }\end{array}$ \\
\hline SLCOIBI (OATPIBI) & $\begin{array}{l}\text { rs4l490I5 } \\
\text { rs } 2306283 \\
\text { rs4I49056 } \\
\text { rs4l49057 }\end{array}$ & 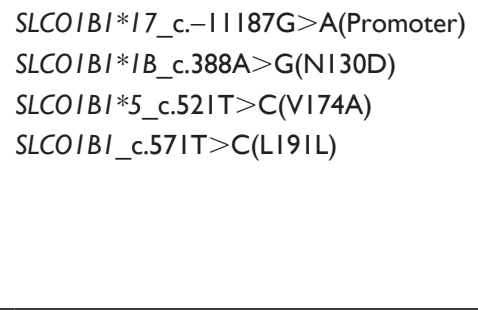 & $\begin{array}{l}0.084 \\
0.269 \\
0.122 \\
0.282\end{array}$ & $\begin{array}{l}\text { - } S L C O I B I * I 7 \text { is associated with the efficacy } \\
\text { and pharmacokinetics of pravastatin }{ }^{82,83} \\
\text { - } S L C O I B I * 5 \text { is associated with high risk } \\
\text { of muscular diseases when treated with } \\
\text { simvastatin } \\
\text { - Other drugs associated with } * 5 \text { variant } \\
\text { include cerivastatin, pravastatin, and } \\
\text { rosuvastatin }{ }^{78,86,87}\end{array}$ \\
\hline
\end{tabular}

Note: dbSNP RS ID is an identification tag assigned by the National Center for Biotechnology Information to a group of single nucelotide polymorphisms (SNPs) that map to an identical location in the SNP database.

Abbreviations: $A B C$, adenosine triphosphate-binding cassette; SLC, solute carrier.

this study, which is in line with the previously reported frequency of $27 \% .{ }^{30}$ CYP2B6 variants, c.516G $>\mathrm{T}$ and c. $785 \mathrm{~A}>\mathrm{G}$, which were strongly correlated with plasma efavirenz levels in the Thai population, are not reported in the findings of this study. ${ }^{31}$ Another variant of a major CYP2B6 enzyme, c.64C $>\mathrm{T}$, which is also associated with efavirenz plasma concentration, was present at a frequency of 0.055 , which is also reported by the earlier study to occur at similar prevalence of 0.06 .

Polymorphisms in Phase II metabolic enzymes and transporters are of clinical significance, because of altered function affecting the drug safety and drug efficacy. ${ }^{32}$ UGT enzyme polymorphisms have been associated with several drug substrates and widely studied among several ethnic groups. ${ }^{33-35}$ The prevalence of $U G T 1 A 1^{*} 6$, which is more commonly observed in Asian populations and absent among Caucasians, resembled earlier studies that reported a frequency of $9 \% .{ }^{36}$ A previous study of $U G T 2 B 7 * 2$ among Thai patients with breast cancer reported an allele frequency of $28 \%,{ }^{37}$ which is similar to the $31.5 \%$ reported in this study. CYP1A2* $1 F$ was associated with an increased risk of cholangiocarcinoma (CCA), while $N A T 2 * 6$ and $* 7$ were associated with a lower risk of CCA in a study by Prawan et al, ${ }^{38}$ who evaluated the relationship between CYP1A2 and NAT2 alleles and CCA among individuals living in the northeastern region of Thailand. The allelic frequencies of $C Y P 1 A 2 * 1 F$, $N A T 2 * 6$, and $N A T 2 * 7$ in this study group were found to be $23.9 \%, 27.7 \%$, and $17.6 \%$, respectively. Genetic variants of 
a widely documented polymorphic enzyme TPMT did not pass quality control in this study group with the exception of one variant, TPMT_c.474C $>$ T, with a prevalence of $22.7 \%$ (data not shown).

Among the genetic polymorphisms of $A B C$ and $S L C$ transporters, we found a modest replication of allele frequency, as was reported in a previous comprehensive study of the frequency of several functional variants known to affect plasma concentration of anti-human immunodeficiency virus drugs among the Thai population, including $A B C B 1$ $(1236 \mathrm{C}>\mathrm{T}, 2677 \mathrm{G}>\mathrm{T}$, and $3435 \mathrm{C}>\mathrm{T}), A B C G 2421 \mathrm{C}>\mathrm{A}$, and $S L C O 1 B 1521 \mathrm{~T}>\mathrm{C} .{ }^{39}$

Limitations in this study include lack of validation data for the markers extracted from the DMET assay. Second, we did not evaluate the clinical role of DMET SNPs in determining the influence on the ASD symptoms. A study by Jiao et $\mathrm{al}^{40}$ has accumulated the evidence of the role of SNPs in the classification of symptom severities among ASD children. It is necessary to analyze the effects of genetic polymorphisms in DMET genes on clinical efficacy and adverse events to amplify the strength of this study. Finally, the small size and inability to compare with the diverse ethnic Thai populations may limit the scope of application of our findings. Further inclusion of control population would have provided more evidence for translating the findings from this study into clinical practice, which was lacking in this study.

\section{Conclusion}

In this study, we have analyzed the DMET SNPs that are increasingly significant in identifying the predicted drug metabolizer phenotypes among individuals. Knowledge of these variations and implementation of this information to correlate these variants with drug response in the Thai population will help us to understand the interindividual variations in response to pharmacological agents. Identification of several functional SNPs in the clinical setting, rather than just the few widely studied SNPs, will provide more concise and predictive value for pharmacotherapy.

\section{Acknowledgments}

This study was supported by grants from the following organizations: 1) Pharmacogenomics for Autistic Child Project, Khoon Poom Foundation, the Project of Her Royal Highness Princess Ubonratana Rajakanya Siriwatana Bhanawadee; 2) Office of the National Research Council of Thailand; 3) Faculty of Medicine Ramathibodi Hospital; and 4) Mahidol University. The authors thank all staff in Yuwaprasart Waithayopathum Child and Adolescent Psychiatric Hospital and all the children and adolescents with ASD who participated in this study.

\section{Disclosure}

The authors report no conflicts of interest in this work.

\section{References}

1. Li J, You Y, Yue W, et al. Genetic evidence for possible involvement of the calcium channel gene CACNA1A in autism pathogenesis in Chinese Han population. PLoS One. 2015;10(11):e0142887.

2. Rose'meyer R. A review of the serotonin transporter and prenatal cortisol in the development of autism spectrum disorders. Mol Autism. 2013;4(1):37.

3. Mezzelani A, Raggi ME, Marabotti A, Milanesi L. Ochratoxin A as possible factor trigging autism and its male prevalence via epigenetic mechanism. Nutr Neurosci. 2016;19(1):43-46.

4. Ghanizadeh A, Tordjman S, Jaafari N. Aripiprazole for treating irritability in children \& adolescents with autism: a systematic review. Indian J Med Res. 2015;142(3):269-275.

5. McQuire C, Hassiotis A, Harrison B, Pilling S. Pharmacological interventions for challenging behaviour in children with intellectual disabilities: a systematic review and meta-analysis. BMC Psychiatry. 2015;15(1):303.

6. Hongkaew Y, Ngamsamut N, Puangpetch A, et al. Hyperprolactinemia in Thai children and adolescents with autism spectrum disorder treated with risperidone. Neuropsychiatr Dis Treat. 2015;11:191-196.

7. Benvenuto A, Battan B, Porfirio MC, Curatolo P. Pharmacotherapy of autism spectrum disorders. Brain Dev. 2013;35(2):119-127.

8. Kapedanovska Nestorovska A, Jakovski K, Naumovska Z, et al. Distribution of the most common genetic variants associated with a variable drug response in the population of the Republic of Macedonia. Balkan J Med Genet. 2014;17(2):5-14.

9. Ma Q, Lu AY. Pharmacogenetics, pharmacogenomics, and individualized medicine. Pharmacol Rev. 2011;63(2):437-459.

10. Gupta PD. Pharmacogenetics, pharmacogenomics and ayurgenomics for personalized medicine: a paradigm shift. Indian J Pharm Sci. 2015;77(2):135-141.

11. Mango R, Vecchione L, Raso B, et al. Pharmacogenomics in cardiovascular disease: the role of single nucleotide polymorphisms in improving drug therapy. Expert Opin Pharmacother. 2005;6(15):2565-2576.

12. Gray IC, Campbell DA, Spurr NK. Single nucleotide polymorphisms as tools in human genetics. Hum Mol Genet. 2000;9(16):2403-2408.

13. Chaudhary R, Singh B, Kumar M, et al. Role of single nucleotide polymorphisms in pharmacogenomics and their association with human diseases. Drug Metab Rev. 2015;47(3):281-290.

14. Holmes A, Murphy DL, Crawley JN. Abnormal behavioral phenotypes of serotonin transporter knockout mice: parallels with human anxiety and depression. Biol Psychiatry. 2003;54(10):953-959.

15. Braam W, Keijzer H, Struijker Boudier H, Didden R, Smits M, Curfs L. CYP1A2 polymorphisms in slow melatonin metabolisers: a possible relationship with autism spectrum disorder? J Intellect Disabil Res. 2013; 57(11):993-1000.

16. Karam RA, Rezk NA, Abdelrahman HM, et al. Catechol-Omethyltransferase Val158Met polymorphism and hyperactivity symptoms in Egyptian children with autism spectrum disorder. Res Dev Disabil. 2013;34(7):2092-2097.

17. Umamaheswaran G, Kumar DK, Adithan C. Distribution of genetic polymorphisms of genes encoding drug metabolizing enzymes \& drug transporters - a review with Indian perspective. Indian J Med Res. 2014; 139(1):27-65.

18. Li J, Bluth MH. Pharmacogenomics of drug metabolizing enzymes and transporters: implications for cancer therapy. Pharmgenomics Pers Med. 2011;4:11-33. 
19. Sim SC, Kacevska M, Ingelman-Sundberg M. Pharmacogenomics of drug-metabolizing enzymes: a recent update on clinical implications and endogenous effects. Pharmacogenomics J. 2013;13(1):1-11.

20. Bonifaz-Pena V, Contreras AV, Struchiner CJ, et al. Exploring the distribution of genetic markers of pharmacogenomics relevance in Brazilian and Mexican populations. PLoS One. 2014;9(11):e112640.

21. Yang L, Price ET, Chang CW, et al. Gene expression variability in human hepatic drug metabolizing enzymes and transporters. PLoS One. 2013;8(4):e60368.

22. Jittikoon J, Mahasirimongkol S, Charoenyingwattana A, et al. Comparison of genetic variation in drug ADME-related genes in Thais with Caucasian, African and Asian HapMap populations. J Hum Genet. Epub 2015 Oct 1.

23. Saldivar JS, Taylor D, Sugarman EA, et al. Initial assessment of the benefits of implementing pharmacogenetics into the medical management of patients in a long-term care facility. Pharmacogenomics Pers Med. 2016;9:1-6.

24. Fernandez CA, Smith C, Yang W, et al. Concordance of DMET plus genotyping results with those of orthogonal genotyping methods. Clin Pharmacol Ther. 2012;92(3):360-365.

25. Hardenbol P, Baner J, Jain M, et al. Multiplexed genotyping with sequence-tagged molecular inversion probes. Nat Biotechnol. 2003; 21(6):673-678.

26. Syvanen AC. Toward genome-wide SNP genotyping. Nat Genet. 2005; 37(suppl):S5-S10.

27. Barrett JC, Fry B, Maller J, Daly MJ. Haploview: analysis and visualization of LD and haplotype maps. Bioinformatics. 2005;21(2):263-265.

28. Chamnanphon M, Pechatanan K, Sirachainan E, et al. Association of CYP2D6 and CYP2C19 polymorphisms and disease-free survival of Thai post-menopausal breast cancer patients who received adjuvant tamoxifen. Pharmgenomics Pers Med. 2013;6:37-48.

29. Manuyakorn W, Siripool K, Kamchaisatian W, et al. Phenobarbitalinduced severe cutaneous adverse drug reactions are associated with CYP2C19*2 in Thai children. Pediatr Allergy Immunol. 2013;24(3): 299-303.

30. Tassaneeyakul W, Tawalee A, Kukongviriyapan V, Blaisdell J, Goldstein JA, Gaysornsiri D. Analysis of the CYP2C19 polymorphism in a North-eastern Thai population. Pharmacogenetics. 2002;12(3): $221-225$.

31. Sukasem C, Chamnanphon M, Koomdee N, et al. High plasma efavirenz concentration and CYP2B6 polymorphisms in Thai HIV-1 infections. Drug Metab Pharmacokinet. 2013;28(5):391-397.

32. Yiannakopoulou E. Pharmacogenomics of phase II metabolizing enzymes and drug transporters: clinical implications. Pharmacogenomics J. 2013;13(2):105-109.

33. Cote JF, Kirzin S, Kramar A, et al. UGT1A1 polymorphism can predict hematologic toxicity in patients treated with irinotecan. Clin Cancer Res. 2007;13(11):3269-3275.

34. Han FF, Guo CL, Yu D, et al. Associations between UGT1A1*6 or UGT1A $1 * 6 / * 28$ polymorphisms and irinotecan-induced neutropenia in Asian cancer patients. Cancer Chemother Pharmacol. 2014;73(4): 779-788.

35. Lankisch TO, Moebius U, Wehmeier M, et al. Gilbert's disease and atazanavir: from phenotype to UDP-glucuronosyltransferase haplotype. Hepatology. 2006;44(5):1324-1332.

36. Sukasem C, Atasilp C, Chansriwong P, Chamnanphon M, Puangpetch A, Sirachainan E. Development of pyrosequencing method for detection of UGT1A1 polymorphisms in Thai colorectal cancers. J Clin Lab Anal. 2016;30(1):84-89.

37. Areepium N, Panomvana D, Rungwanonchai P, Sathaporn S, Voravud N. Effects of CYP2D6 and UGT2B7 polymorphisms on pharmacokinetics of tamoxifen in Thai breast cancer patients. Breast Cancer (Dove Med Press). 2013;5:73-78.

38. Prawan A, Kukongviriyapan V, Tassaneeyakul W, Pairojkul C, Bhudhisawasdi V. Association between genetic polymorphisms of CYP1A2, arylamine $\mathrm{N}$-acetyltransferase 1 and 2 and susceptibility to cholangiocarcinoma. Eur J Cancer Prev. 2005;14(3):245-250.
39. Chaikan A, Chierakul N, Saguenwong N, et al. Frequency of functional drug disposition gene polymorphism in Thai population: relevance to antiretroviral drugs. In: Ninth International Congress on Drug Therapy in HIV Infection; 2008; Glasgow.

40. Jiao Y, Chen R, Ke X, et al. Single nucleotide polymorphisms predict symptom severity of autism spectrum disorder. J Autism Dev Disord. 2012;42(6):971-983.

41. Dong N, Yu J, Wang C, et al. Pharmacogenetic assessment of clinical outcome in patients with metastatic breast cancer treated with docetaxel plus capecitabine. J Cancer Res Clin Oncol. 2012;138(7):1197-1203.

42. Yoon Y, Park HD, Park KU, Kim JQ, Chang YS, Song J. Associations between CYP2E1 promoter polymorphisms and plasma 1,3-dimethyluric acid/theophylline ratios. Eur J Clin Pharmacol. 2006;62(8):627-631.

43. Tiwari AK, Deshpande SN, Rao AR, et al. Genetic susceptibility to tardive dyskinesia in chronic schizophrenia subjects: I. Association of CYP1A2 gene polymorphism. Pharmacogenomics J. 2005;5(1):60-69.

44. Laika B, Leucht S, Heres S, Schneider H, Steimer W. Pharmacogenetics and olanzapine treatment: CYP1A2*1F and serotonergic polymorphisms influence therapeutic outcome. Pharmacogenomics $J$. 2010;10(1):20-29.

45. Haas DW, Kwara A, Richardson DM, et al. Secondary metabolism pathway polymorphisms and plasma efavirenz concentrations in HIVinfected adults with CYP2B6 slow metabolizer genotypes. J Antimicrob Chemother. 2014;69(8):2175-2182.

46. Manosuthi W, Sukasem C, Lueangniyomkul A, et al. Impact of pharmacogenetic markers of CYP2B6, clinical factors, and drug-drug interaction on efavirenz concentrations in HIV/tuberculosis-coinfected patients. Antimicrob Agents Chemother. 2013;57(2):1019-1024.

47. Mukonzo JK, Nanzigu S, Waako P, Ogwal-Okeng J, Gustafson LL, Aklillu E. CYP2B6 genotype, but not rifampicin-based anti-TB cotreatments, explains variability in long-term efavirenz plasma exposure. Pharmacogenomics. 2014;15(11):1423-1435.

48. van der Weide J, van Baalen-Benedek EH, Kootstra-Ros JE. Metabolic ratios of psychotropics as indication of cytochrome P450 2D6/2C19 genotype. Ther Drug Monit. 2005;27(4):478-483.

49. Cui H, Lin S, Chen X, et al. Correlation between SNPs in candidate genes and VerifyNow-detected platelet responsiveness to aspirin and clopidogrel treatment. Cardiovasc Drugs Ther. 2015;29(2): 137-146.

50. Horenstein RB, Madabushi R, Zineh I, et al. Effectiveness of clopidogrel dose escalation to normalize active metabolite exposure and antiplatelet effects in CYP2C19 poor metabolizers. J Clin Pharmacol. 2014; 54(8):865-873.

51. Rudberg I, Hermann M, Refsum H, Molden E. Serum concentrations of sertraline and N-desmethyl sertraline in relation to CYP2C19 genotype in psychiatric patients. Eur J Clin Pharmacol. 2008;64(12): 1181-1188.

52. Chang M, Tybring G, Dahl ML, Lindh JD. Impact of cytochrome P450 2C19 polymorphisms on citalopram/escitalopram exposure: a systematic review and meta-analysis. Clin Pharmacokinet. 2014;53(9):801-811.

53. Penas-Lledo EM, Trejo HD, Dorado P, et al. CYP2D6 ultrarapid metabolism and early dropout from fluoxetine or amitriptyline monotherapy treatment in major depressive patients. Mol Psychiatry. 2013; 18(1):8-9.

54. Wu X, Yuan L, Zuo J, Lv J, Guo T. The impact of CYP2D6 polymorphisms on the pharmacokinetics of codeine and its metabolites in Mongolian Chinese subjects. Eur J Clin Pharmacol. 2014;70(1):57-63.

55. Hodgson K, Tansey K, Dernovsek MZ, et al. Genetic differences in cytochrome P450 enzymes and antidepressant treatment response. J Psychopharmacol. 2014;28(2):133-141.

56. Jurica J, Zourkova A. Dynamics and persistence of CYP2D6 inhibition by paroxetine. J Clin Pharm Ther. 2013;38(4):294-300.

57. Kirchheiner J, Keulen JT, Bauer S, Roots I, Brockmoller J. Effects of the CYP2D6 gene duplication on the pharmacokinetics and pharmacodynamics of tramadol. J Clin Psychopharmacol. 2008;28(1): 78-83. 
58. Nair SS, Sarasamma S, Gracious N, George J, Anish TS, Radhakrishnan R. Polymorphism of the CYP3A5 gene and its effect on tacrolimus blood level. Exp Clin Transplant. 2015;13(suppl 1):197-200.

59. Birdwell KA, Grady B, Choi L, et al. The use of a DNA biobank linked to electronic medical records to characterize pharmacogenomic predictors of tacrolimus dose requirement in kidney transplant recipients. Pharmacogenet Genomics. 2012;22(1):32-42.

60. Chung JY, Cho JY, Yu KS, et al. Pharmacokinetic and pharmacodynamic interaction of lorazepam and valproic acid in relation to UGT2B7 genetic polymorphism in healthy subjects. Clin Pharmacol Ther. 2008; 83(4):595-600.

61. Takekuma Y, Takenaka T, Kiyokawa M, et al. Evaluation of effects of polymorphism for metabolic enzymes on pharmacokinetics of carvedilol by population pharmacokinetic analysis. Biol Pharm Bull. 2007; 30(3):537-542.

62. Ten Brink MH, Swen JJ, Bohringer S, et al. Exploratory analysis of 1936 SNPs in ADME genes for association with busulfan clearance in adult hematopoietic stem cell recipients. Pharmacogenet Genomics. 2013;23(12):675-683.

63. Zhang BL, Sun T, Zhang BN, et al. Polymorphisms of GSTP1 is associated with differences of chemotherapy response and toxicity in breast cancer. Chin Med J (Engl). 2011;124(2):199-204.

64. Lamas MJ, Duran G, Balboa E, et al. Use of a comprehensive panel of biomarkers to predict response to a fluorouracil-oxaliplatin regimen in patients with metastatic colorectal cancer. Pharmacogenomics. 2011; 12(3):433-442.

65. Shroads AL, Langaee T, Coats BS, et al. Human polymorphisms in the glutathione transferase zeta $1 /$ maleylacetoacetate isomerase gene influence the toxicokinetics of dichloroacetate. J Clin Pharmacol. 2012; 52(6):837-849.

66. Gupta VH, Amarapurkar DN, Singh M, et al. Association of $\mathrm{N}$-acetyltransferase 2 and cytochrome P450 2E1 gene polymorphisms with antituberculosis drug-induced hepatotoxicity in Western India. J Gastroenterol Hepatol. 2013;28(8):1368-1374.

67. Verhagen LM, Coenen MJ, Lopez D, et al. Full-gene sequencing analysis of NAT2 and its relationship with isoniazid pharmacokinetics in Venezuelan children with tuberculosis. Pharmacogenomics. 2014; 15(3):285-296.

68. Wu H, Kang H, Liu Y, et al. Association of ABCB1 genetic polymorphisms with susceptibility to colorectal cancer and therapeutic prognosis. Pharmacogenomics. 2013;14(8):897-911.

69. Aarnoudse AJ, Dieleman JP, Visser LE, et al. Common ATP-binding cassette B1 variants are associated with increased digoxin serum concentration. Pharmacogenet Genomics. 2008;18(4):299-305.

70. Ciccacci C, Borgiani P, Ceffa S, et al. Nevirapine-induced hepatotoxicity and pharmacogenetics: a retrospective study in a population from Mozambique. Pharmacogenomics. 2010;11(1):23-31.

71. Caronia D, Patino-Garcia A, Perez-Martinez A, et al. Effect of ABCB1 and $\mathrm{ABCC} 3$ polymorphisms on osteosarcoma survival after chemotherapy: a pharmacogenetic study. PLoS One. 2011;6(10):e26091.

72. Coelho AV, Silva SP, de Alencar LC, et al. ABCB1 and ABCC1 variants associated with virological failure of first-line protease inhibitors antiretroviral regimens in Northeast Brazil patients. J Clin Pharmacol. 2013;53(12):1286-1293
73. Qu J, Zhou BT, Yin JY, et al. ABCC2 polymorphisms and haplotype are associated with drug resistance in Chinese epileptic patients. CNS Neurosci Ther. 2012;18(8):647-651.

74. Franke RM, Lancaster CS, Peer CJ, et al. Effect of ABCC2 (MRP2) transport function on erythromycin metabolism. Clin Pharmacol Ther. 2011;89(5):693-701.

75. Lee KH, Chang HJ, Han SW, et al. Pharmacogenetic analysis of adjuvant FOLFOX for Korean patients with colon cancer. Cancer Chemother Pharmacol. 2013;71(4):843-851.

76. Haenisch S, May K, Wegner D, Caliebe A, Cascorbi I, Siegmund W. Influence of genetic polymorphisms on intestinal expression and rifampicin-type induction of $\mathrm{ABCC} 2$ and on bioavailability of talinolol. Pharmacogenet Genomics. 2008;18(4):357-365.

77. Fujita K, Nagashima F, Yamamoto W, et al. Association of ATP-binding cassette, sub-family $\mathrm{C}$, number 2 (ABCC2) genotype with pharmacokinetics of irinotecan in Japanese patients with metastatic colorectal cancer treated with irinotecan plus infusional 5-fluorouracil/leucovorin (FOLFIRI). Biol Pharm Bull. 2008;31(11):2137-2142.

78. DeGorter MK, Tirona RG, Schwarz UI, et al. Clinical and pharmacogenetic predictors of circulating atorvastatin and rosuvastatin concentrations in routine clinical care. Circ Cardiovasc Genet. 2013; 6(4):400-408.

79. Lee HK, Hu M, Lui S, Ho CS, Wong CK, Tomlinson B. Effects of polymorphisms in ABCG2, SLCO1B1, SLC10A1 and CYP2C9/19 on plasma concentrations of rosuvastatin and lipid response in Chinese patients. Pharmacogenomics. 2013;14(11):1283-1294.

80. Di Paolo A, Polillo M, Capecchi M, et al. The c. $480 \mathrm{C}>$ G polymorphism of hOCT1 influences imatinib clearance in patients affected by chronic myeloid leukemia. Pharmacogenomics J. 2014;14(4):328-335.

81. Tarasova L, Kalnina I, Geldnere K, et al. Association of genetic variation in the organic cation transporters OCT1, OCT2 and multidrug and toxin extrusion 1 transporter protein genes with the gastrointestinal side effects and lower BMI in metformin-treated type 2 diabetes patients. Pharmacogenet Genomics. 2012;22(9):659-666.

82. Niemi M, Neuvonen PJ, Hofmann U, et al. Acute effects of pravastatin on cholesterol synthesis are associated with SLCO1B1 (encoding OATP1B1) haplotype *17. Pharmacogenet Genomics. 2005; 15(5):303-309.

83. Niemi M, Schaeffeler E, Lang T, et al. High plasma pravastatin concentrations are associated with single nucleotide polymorphisms and haplotypes of organic anion transporting polypeptide-C (OATP-C, SLCO1B1). Pharmacogenetics. 2004;14(7):429-440.

84. Brunham LR, Lansberg PJ, Zhang L, et al. Differential effect of the rs4149056 variant in SLCO1B1 on myopathy associated with simvastatin and atorvastatin. Pharmacogenomics J. 2012;12(3):233-237.

85. SEARCH Collaborative Group, Link E, Parish S, et al. SLCO1B1 variants and statin-induced myopathy - a genomewide study. $N$ Engl J Med. 2008;359(8):789-799.

86. Marciante KD, Durda JP, Heckbert SR, et al. Cerivastatin, genetic variants, and the risk of rhabdomyolysis. Pharmacogenet Genomics. 2011; 21(5):280-288.

87. Ho RH, Choi L, Lee W, et al. Effect of drug transporter genotypes on pravastatin disposition in European- and African-American participants. Pharmacogenet Genomics. 2007;17(8):647-656.
Neuropsychiatric Disease and Treatment

\section{Publish your work in this journal}

Neuropsychiatric Disease and Treatment is an international, peerreviewed journal of clinical therapeutics and pharmacology focusing on concise rapid reporting of clinical or pre-clinical studies on a range of neuropsychiatric and neurological disorders. This journa is indexed on PubMed Central, the 'PsycINFO' database and CAS,

\section{Dovepress}

and is the official journal of The International Neuropsychiatric Association (INA). The manuscript management system is completely online and includes a very quick and fair peer-review system, which is all easy to use. Visit http://www.dovepress.com/testimonials.php to read real quotes from published authors. 